\title{
Infection with Edwardsiella tarda causes hypertrophy of liver cells in the Japanese flounder Paralichthys olivaceus
}

\author{
Satoshi Miwa*, Nobuhiro Mano \\ National Research Institute of Fisheries Science, 2-12-4, Fukuura, Kanazawa, Yokohama 236-8648, Japan
}

\begin{abstract}
To study the direct cause of liver enlargement in the Japanese flounder Paralichthys olivaceus infected with Edwardsiella tarda, the fish were challenged with E. tarda and reared without feeding. The liver of fish exposed to the bacteria was markedly enlarged compared to that of the controls while no severe histopathological change appeared in the organ during the experiments. No notable difference was observed in the crude fat, glycogen, and water content of the liver between challenged and control fish. The size of liver cells and nuclei of the challenged fish was apparently larger than that of the controls. Analysis of crude DNA in the liver suggested that the number of liver cells of starved control fish significantly decreased during the experiment while that of the challenged fish was maintained at a level of the initial control. RNA/DNA ratio of the liver of challenged fish clearly increased while it decreased in the control fish during the experiment. These observations suggest that liver enlargement of flounder infected with E. tarda, at least in the early stage of infection, is not a result of any readily observable histopathological changes and that E. tarda infection causes hypertrophy of the cells, as well as preventing decrease in liver cell number.
\end{abstract}

KEY WORDS: Edwardsiella tarda $\cdot$ Flounder $\cdot$ Paralichthys olivaceus $\cdot$ Liver $\cdot$ Enlargement $\cdot$ Histopathology

Resale or republication not permitted without written consent of the publisher

Edwardsiella tarda is one of the major bacterial pathogens of Japanese flounder Paralichthys olivaceus and several other cultured fish species in Japan (Kusuda \& Kawai 1998). Abscesses or granulomas containing the bacteria are commonly formed in various organs (Miyazaki \& Kaige 1985). Swelling of the liver is also reported in E. tarda-infected eel (Miyazaki \& Kaige 1985) and flounder (Nakatsugawa 1983). Since abscesses are also formed in the liver of infected flounder (Mammur Rashid et al. 1997), it seems reasonable

*E-mail: miwasat@nrifs.affrc.go.jp to ascribe the swelling of the liver to these histopathological changes. However, we have noticed that the liver of the Japanese flounder infected with E. tarda was sometimes enlarged while no histopathological changes had appeared in the organ. Thus, the present study was conducted, first to confirm that the swelling of the liver in the E. tarda-infected flounder is not the result of any histopathological changes developed in the organ, and if not, to study the direct cause of liver enlargement. Fish were exposed to E. tarda by immersion in seawater containing the bacteria, since this would minimize bacterial infection in the liver compared to intraperitoneal injection or oral administration (Mammur Rashid et al. 1997). In order to analyze the liver before pathological changes appear, fish were sampled within $8 \mathrm{~d}$ after bacterial challenge.

Materials and methods. Fry of Japanese flounder were purchased from a private hatchery (Nisshin Marine Tech Co., Aichi, Japan). These fish were stocked in an aquarium in the laboratory, fed commercial pellet diet, and raised at $20^{\circ} \mathrm{C}$ until experiments.

A virulent strain of Edwardsiella tarda (designated $\mathrm{HH}-1)$ used for the present study, was originally isolated from a diseased Japanese flounder and tested for virulence by inoculation into flounder at Hyogo Prefectural Fisheries Research Station. Freeze-dried bacteria was rehydrated in heart infusion (HI) broth (Eiken Chemical, Tokyo, Japan) containing 0.5\% $\mathrm{NaCl}$ and inoculated on $\mathrm{HI}$ agar at $20^{\circ} \mathrm{C}$ for $48 \mathrm{~h}$. Subsequently, the bacteria were harvested, suspended in $\mathrm{HI}$ broth containing $0.5 \% \mathrm{NaCl}$ and $10 \%$ glycerol, and aliquots were stored at $-80^{\circ} \mathrm{C}$. To prepare the challenge inoculum for each experiment, a stored aliquot was cultured on $\mathrm{HI}$ agar at $20^{\circ} \mathrm{C}$ for $48 \mathrm{~h}$, then suspended in $1 \mathrm{l}$ of $\mathrm{HI}$ broth containing $0.5 \% \mathrm{NaCl}$ and grown at $20^{\circ} \mathrm{C}$ for $20 \mathrm{~h}$. The number of the bacteria $\left(\mathrm{CFU} \mathrm{m} \mathrm{m}^{-1}\right.$ ) was quantified by serial dilution of the inoculum on HI agar. 
Three experiments were carried out at different times (designated Expts 1, 2, and 3). In each experiment, fish were randomly selected from the stock aquarium and immersed in seawater containing $E d$ wardsiella tarda $\left(8.2,6.0\right.$, and $10 \times 10^{7} \mathrm{CFU} \mathrm{m}^{-1}$ for Expts 1, 2, and 3, respectively) for $30 \mathrm{~min}$, and transferred into the experimental aquarium filled with $300 \mathrm{l}$ of running and aerated seawater at $20^{\circ} \mathrm{C}$. The fish were kept without feeding during experiments. The numbers of fish used for the bacterial challenges were 22, 27, and 17 for Expts 1, 2, and 3, respectively. For the control, the same number of fish from the stock were immersed in seawater without E. tarda and reared similarly thereafter without feeding. The control fish were simultaneously treated and sampled with the challenged fish. The body weights of fish were $31.2 \pm 1.1$, $52.4 \pm 1.9$, and $54.7 \pm 0.9 \mathrm{~g}($ mean $\pm \mathrm{SE})$ for Expts 1, 2, and 3, respectively. For Expts 1 and 2, fish were fed until the day before the challenge, whereas feeding was stopped $3 \mathrm{~d}$ prior to the challenge in Expt 3, to decrease the liver weight until the start of the experiment and to confirm that the liver is actually enlarged by the infection. In the Expt 1, 5 fish were sampled at $1,3,5$, and $8 \mathrm{~d}$ after the exposure to the bacteria respectively from each group, and crude liver fat, water content of the liver, and plasma glucose were determined. In Expt 2, 10 fish were sampled at 3 and $5 \mathrm{~d}$ after the bacterial challenge, respectively, from each group. The livers from 5 fish were analyzed for glycogen and those from the other 5 were used to extract soluble proteins for the analysis with SDSPAGE. Plasma glucose was also measured. In Expt 3, 10 fish were sampled from each group at $5 \mathrm{~d}$ after the exposure to the bacteria, and the livers were subjected to DNA and RNA content analysis. For each experiment, 5 or 10 fish were sampled from the stocked group at the start of the experiment as the initial control.

At sampling, each fish was anesthetized with 1/5000 ethyl m-aminobenzoate (Sigma), weighed, and blood was withdrawn from the caudal artery/vein with a heparinized syringe. When necessary, plasma was separated by centrifugation and stored at $-80^{\circ} \mathrm{C}$. Portions of the liver and kidney were aseptically removed and streaked on SS (Salmonella-Shigella) agar (Eiken) to confirm the infection of Edwardsiella tarda, except at the sampling $1 \mathrm{~d}$ after the challenge in the Expt 1. Preliminary experiments showed that E. tarda produces black pigment on SS agar. Subsequently, the whole liver was removed and weighed together with the portion used for the bacterial detection to calculate hepatosomatic index (HSI, percent of the liver weight against the body weight). Part of the liver was fixed in Davidson's fixative for histopathology and the rest was stored at $-80^{\circ} \mathrm{C}$ for later analyses. The SDS-PAGE samples of soluble proteins were prepared as follows: part of the liver was weighed and immediately homogenized in 3 volumes of $10 \mathrm{mM}$ phosphate buffer (pH 7.4) containing $1 \mathrm{mM}$ diisopropylfluorophosphate (DFP) (Wako Pure Chemical Industries, Osaka, Japan), $0.1 \mathrm{mM}$ L-3-carboxy-trans-2,3-epoxypropionyl-L-leucine-4-guanidinobutyl-amide (E-64) (Peptide Institute, Osaka, Japan), $0.1 \mathrm{mM}$ pepstatin (Peptide Institute), and $1 \mathrm{mM}$ ethylenediaminetetraacetic acid (EDTA) disodium salt (Wako) with Polytron (Switzerland) homogeniser. The homogenate was centrifuged at $10000 \times g$ for $25 \mathrm{~min}$ and the supernatant was stored as the extract at $-80^{\circ} \mathrm{C}$ until analysis. The preparation of the SDS-PAGE samples was carried out at 0 to $4^{\circ} \mathrm{C}$.

Plasma glucose was determined by the mutarotaseglucoseoxidase method (Glucose CII-TEST, Wako). Water content was determined by drying the liver to constant weight in a drying oven at $110^{\circ} \mathrm{C}$. Crude fat in the liver was measured by ether extraction. Liver glycogen content was estimated by sulfuric acid-anthrone method after partially purified by digestion of the tissue in hot $\mathrm{KOH}$ solution, elimination of protein with trichloroacetic acid, and precipitation with ethanol. For the determination of DNA and RNA, nucleic acids were extracted from the liver principally according to the method of Schneider (1957). DNA and RNA were determined from the absorbency of the hydrolysates at $260 \mathrm{~nm}$. The extract of the liver soluble proteins were subjected to SDS-PAGE under reducing conditions using $10 \%$ separating gel and stained with Coomassie Brilliant Blue R-250.

Two sets of sections were prepared and stained with either haematoxylin-eosin or May-Gruenwald-Giemsa for light microscopy. Area of abscesses and the nuclei of liver cells were determined with IMAGING PRIMER (Rio Grande Software, Austin, TX, USA) by manually outlining the objects. An area of about 30 nuclei was measured for each fish, and the average was used as the area of the liver cell nuclei for the individual fish.

A $t$-test was used to compare the differences of means, on the assumption that the variance is not equal between the samples, unless otherwise indicated.

Results and discussion. Two fish of the challenged group were found dead on Day 8 post exposure in Expt 1. No mortality was observed in the other 2 experiments.

The liver of the challenged fish became markedly larger than the control fish in all experiments. On Day 3 and thereafter, the fish in the challenged group exhibited significantly higher HSI than that of the control fish in Expt 1, while HSI of the control group continued to decrease during the experiment (Fig.1). Principally the same results were obtained in the Expt 2 (data not shown). HSI of the challenged fish $($ mean $\pm \mathrm{SE}=1.21 \pm 0.05)$ increased significantly 


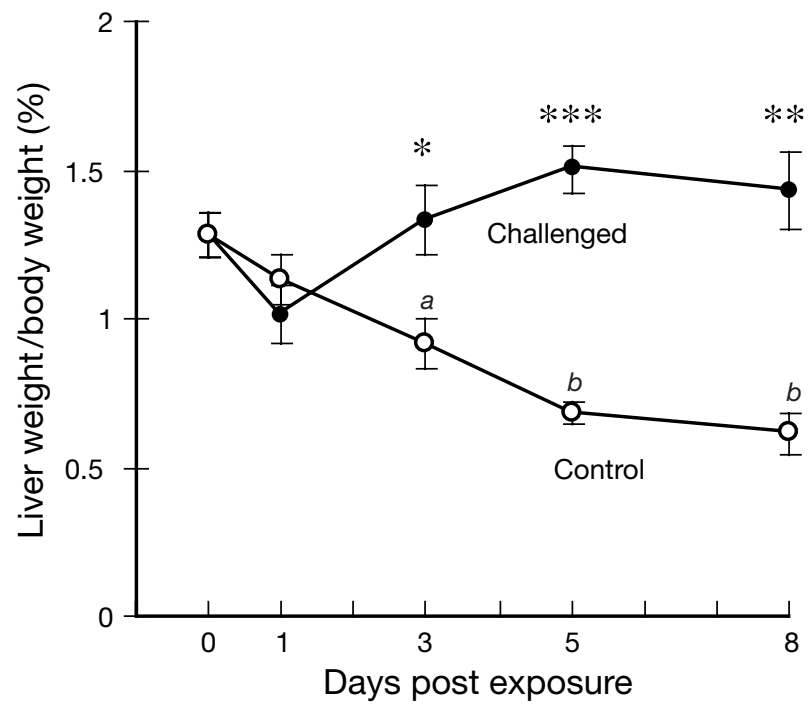

Fig. 1. Paralichthys olivaceus infected with Edwardsiella tarda. Changes in the liver weight/body weight ratio of the flounder after exposure to E. tarda. Values are expressed as mean \pm SE. Asterisks indicate that the value is significantly different from the corresponding control $\left(* \mathrm{p}<0.05 ; * * \mathrm{p}<5 \times 10^{-3}\right.$; $\left.* * * \mathrm{p}<5 \times 10^{-4}\right)$. Symbols with letters $a$ and $b$ are significantly different from the initial control $\left(a, \mathrm{p}<0.05 ; b, \mathrm{p}<5 \times 10^{-4}\right)$

$\left(p<5 \times 10^{-3}\right)$ from the initial control $(0.93 \pm 0.07)$ following bacterial challenge in Expt 3. Mild ascites was found in some of the fish exposed to the bacteria.

The only histopathological change found in the present study was the development of a few microabscesses in the liver of 1 of 5 challenged fish sampled on Day 5 , and 1 of 5 challenged fish sampled on Day 8 in the Expt 1. Microabscesses were also found in 3 of 10 fish challenged and sampled on Day 5 in the Expt 3. Bacteria were always found in the phagocytes in these abscesses. The morphology of the abscesses was the same as described by Mammur Rashid et al. (1997). However, the abscesses were all small, and even in the most severe case, the area of abscesses was only $1 \%$ of the liver section. No histopathological changes in the liver were observed in Expt 2. Hence, it is impossible to

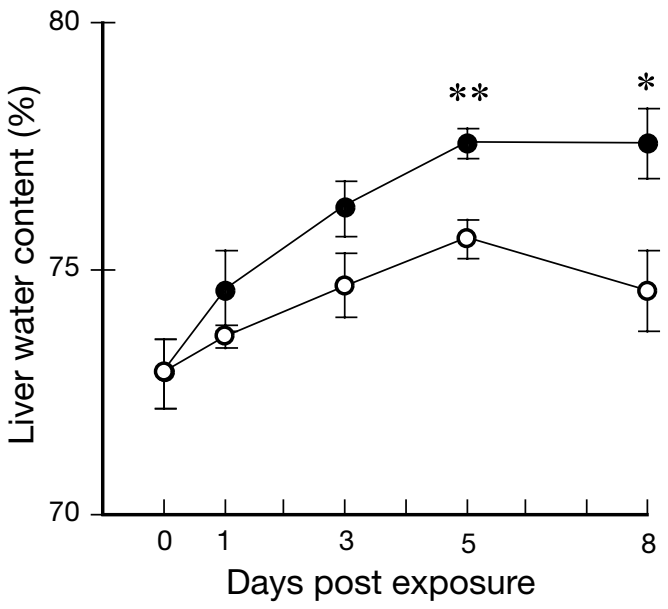

Fig. 2. Paralichthys olivaceus infected with Edwardsiella tarda. Changes in liver water content of the flounder after exposure to E. tarda. (0) Control; (๑) challenged. Values are expressed as mean $\pm \mathrm{SE}$. Asterisks indicate that the value is significantly different from the corresponding control $(* \mathrm{p}<$ $0.05 ; * * \mathrm{p}<5 \times 10^{-3}$ )

attribute the cause of the liver swelling to the formation of the abscesses. Analysis of water content in the livers also indicates that enlargement of the liver is not the result of oedema, since the difference in the water content between the control and challenged fish is too small to explain the difference in the HSI of the 2 groups (Fig. 2). Therefore, the liver enlargement found in the present experiments was not a result of any degenerative changes or inflammatory responses in the tissue. The result of the bacterial culture, in which the liver was often culture-negative, also supports this conclusion (Table 1).

The analyses of crude fat and glycogen content revealed that the liver swelling was not caused by an increase in these substances. On the contrary, the percentage of these substances, particularly glycogen, decreased, although not significantly ( $p>0.05)$, in the challenged fish (data not shown).

On the other hand, the liver RNA/DNA ratio of the challenged fish increased markedly as compared to

Table 1. Paralichthys olivaceus infected with Edwardsiella tarda. Number of fish positive for E. tarda after exposure to the bacteria. Numbers in parentheses indicate the number of fish tested. Morphologically only 1 bacterial colony type, which produced a black pigment on the SS agar, was isolated from the fish exposed to the bacteria, and this was considered E. tarda. No bacteria were detected from the fish of any control groups

\begin{tabular}{|c|c|c|c|c|c|c|}
\hline \multirow{2}{*}{$\begin{array}{l}\text { Day } \\
\text { post exposure }\end{array}$} & \multicolumn{2}{|c|}{ Expt 1} & \multicolumn{2}{|c|}{ Expt 2} & \multicolumn{2}{|c|}{ Expt 3} \\
\hline & Liver & Kidney & Liver & Kidney & Liver & Kidney \\
\hline 3 & $3(5)$ & $5(5)$ & $4(10)$ & $10(10)$ & - & - \\
\hline 5 & $3(5)$ & 5 (5) & $3(10)$ & $8(10)$ & $5(10)$ & $9(10)$ \\
\hline 8 & $5(5)$ & 5 (5) & - & - & - & - \\
\hline
\end{tabular}




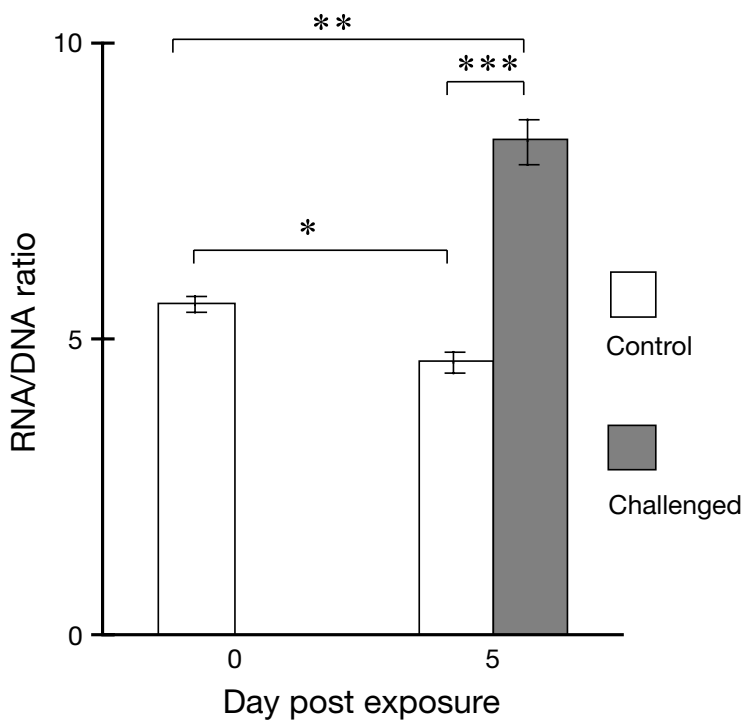

Fig. 3. Paralichthys olivaceus infected with Edwardsiella tarda. Weight ratio of RNA/DNA in a unit weight of the liver of the flounder exposed to E. tarda. Values are expressed as mean \pm SE. Asterisks indicate significant difference $\left(* \mathrm{p}<1 \times 10^{-3}\right.$; $\left.* * \mathrm{p}<5 \times 10^{-5} ; * * * \mathrm{p}<1 \times 10^{-6}\right)$

that of the initial control, while the ratio of control fish decreased significantly (Fig. 3). This strongly suggests that protein synthesis or gene transcription in liver cells were markedly stimulated by the infection of Edwardsiella tarda. The DNA content/unit liver weight $\left(1.50 \pm 0.07 \mathrm{~g} \mathrm{mg}^{-1}\right.$ for the initial control) significantly decreased in the fish exposed to the bacteria $(1.14 \pm$ $\left.0.05, \mathrm{p}<5 \times 10^{-3}\right)$, whereas the value increased in control fish $(1.72 \pm 0.03, p<0.05)$. This suggests an increase in the size of each liver cell in the infected fish. Liver histology not only confirmed this, but also re-

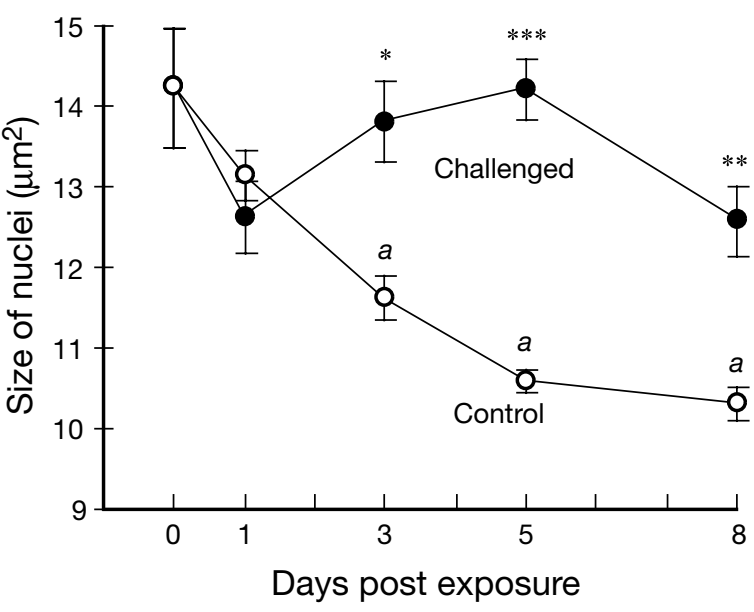

Fig. 5. Paralichthys olivaceus infected with Edwardsiella tarda. Changes in the size of the liver cell nuclei of the flounder after exposure to E. tarda. Values are expressed as mean $\pm \mathrm{SE}$. Asterisks indicate that the value is significantly different from the corresponding control $\left(* \mathrm{p}<0.01 ; * * \mathrm{p}<5 \times 10^{-3} ; * * * \mathrm{p}<5 \times\right.$ $\left.10^{-4}\right)$. Symbols with letter $a$ are significantly different from the initial control $(p<0.05)$

vealed that the size of the nuclei of liver cells increased in the fish exposed to the bacteria (Figs. 4 \& 5). The total liver DNA/body weight of the challenged fish $\left(13.71 \pm 0.53 \mu \mathrm{g} \mathrm{g}^{-1}\right)$ sampled on Day 5 was almost unchanged from the initial control $(13.49 \pm 0.45)$. However, the value of the control fish sampled on Day 5 $(10.97 \pm 0.37)$ was significantly smaller than these 2 groups $\left(\mathrm{p}<1 \times 10^{-3}\right.$; a $t$-test was conducted on the assumption that the variance was equal among the 3 groups). This suggests that, in starved flounder, the liver cells are not only atrophied but the number of the cells is also decreased. This might be a physiological
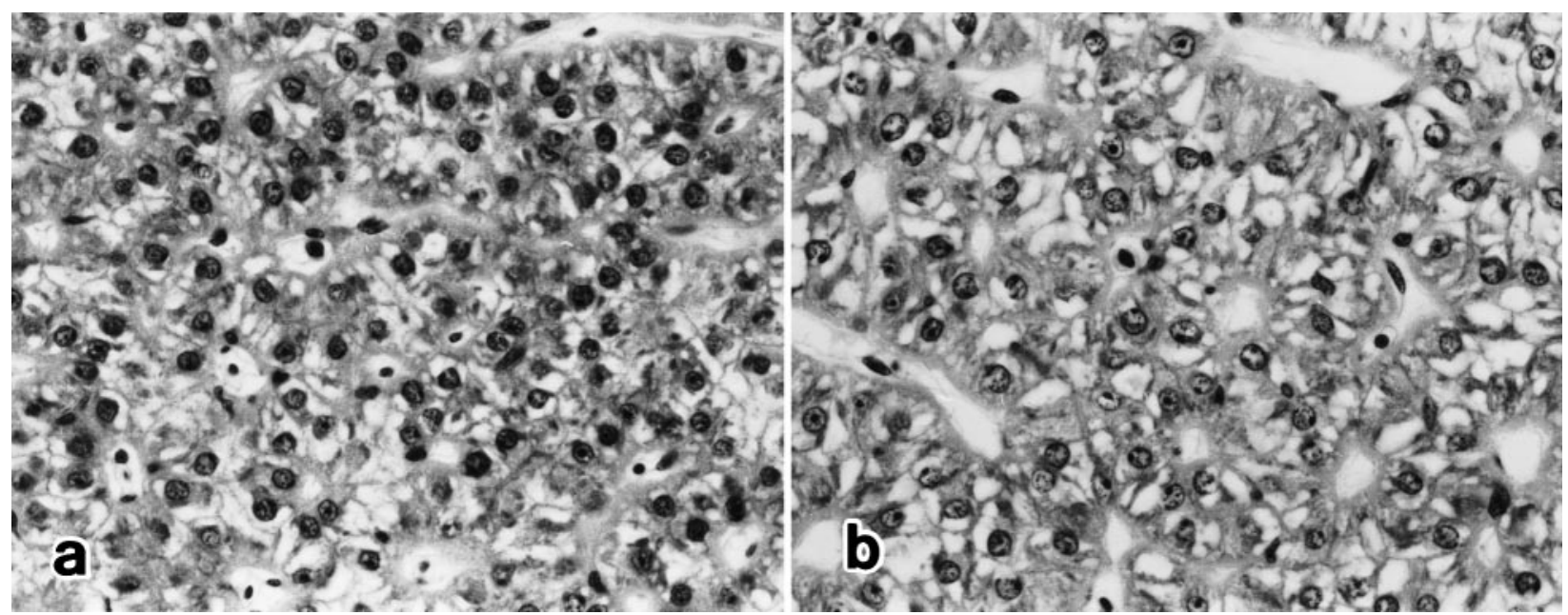

Fig. 4. Paralichthys olivaceus infected with Edwardsiella tarda. Liver tissue of the flounder 5 d post exposure in Expt 1. (a) Control; (b) challenged with E. tarda. Note that the distribution of cell nuclei in the control is denser than that of the challenged fish, whereas the size of cell nuclei of the challenged fish is larger than that of the control. H\&E. $\times 577$ 


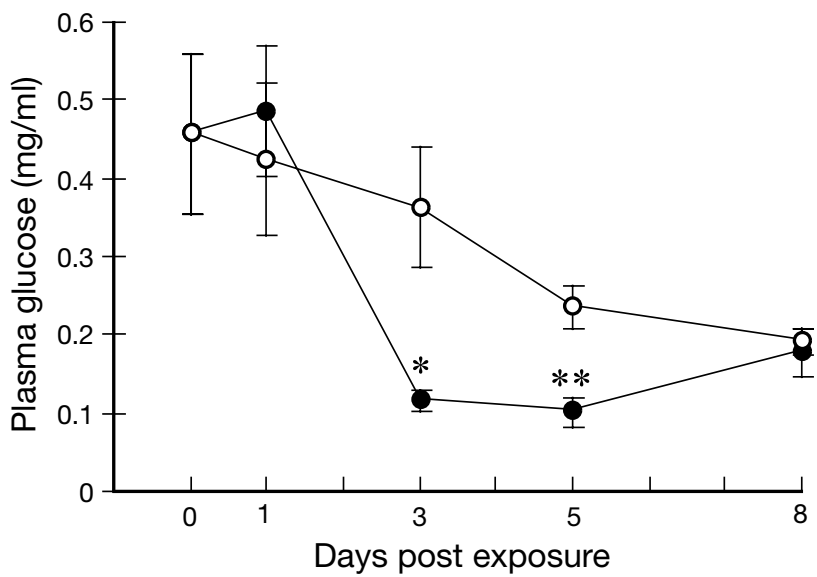

Fig. 6. Paralichthys olivaceus infected with Edwardsiella tarda. Changes in plasma glucose in flounder after exposure to $E$. tarda. (0) Control; (๑) challenged. Values are expressed as mean \pm SE. Asterisks indicate that the value is significantly different from the corresponding control $\left(* \mathrm{p}<0.05 ; * * \mathrm{p}<5 \times 10^{-3}\right)$

adaptation of the flounder to starvation, but the mechanism by which the number of liver cells is controlled remains unknown.

These observations suggest that the enlargement of the liver in flounder exposed to Edwardsiella tarda is the direct result of the activation and hypertrophy of the liver cells, as well as the larger number of the cells. Mammur Rashid et al. (1997) reported that the liver cells of moribund flounder infected with E. tarda were atrophic. This is probably because these authors observed the tissue of moribund fish, and the liver cells might also have become atrophic in the present experiments if the fish had been kept until the infection became very severe.

However, we could not find any differences in the SDS-PAGE patterns of the liver soluble proteins between the control and infected groups (data not shown); therefore, it is not yet clear whether transcription or synthesis of any particular genes or proteins are activated in the challenged fish. Thus, the physiological significance of the liver cell hypertrophy is still unknown.

The carbohydrate metabolism of the flounder was altered by the Edwardsiella tarda infection. In the infected fish, the plasma glucose level was significantly lower than that of the corresponding control fish on

Editorial responsibility: David Bruno, Aberdeen, Scotland, UK
Days 3 and 5 (Fig. 6). Interestingly, this is not caused by the increased glyconeogenesis in the liver, since the tissue glycogen level did not change significantly in the challenged fish. The protein metabolism may also have been changed in infected fish. If the protein synthesis was activated in the hypertrophied liver of the challenged fish as suggested above, what was the source of amino acids? Since the fish were kept without feeding during the experiments, the amino acids must have been provided from within the fish body, possibly by degradation of structural proteins.

It is uncertain whether the hypertrophy of the liver in fish exposed to bacteria is limited to Edwardsiella tarda or rather a general response to bacterial infection. It is also unknown whether the liver hypertrophy can be induced in other fish species by E. tarda infection. Swelling of the liver was reported in the Japanese eel Anguilla japonica infected with E. tarda (Miyazaki \& Kaige 1985), although the nature of this liver swelling is unclear. It seems plausible that liver hypertrophy, as observed in the present study, has often been overlooked, since an enlargement of the liver of challenged fish is unclear when the size of the liver is compared with well-fed initial controls and only becomes evident when compared with starved control fish. The specificity of the liver hypertrophy and the mechanism by which E. tarda stimulates liver cell activity is the subject of our current investigation.

Acknowledgements. We thank Dr A. Mizuta, Hyogo Prefectural Fisheries Research Station, for providing Edwardsiella tarda, and Dr F. Aranishi, National Research Institute of Fisheries Science, for technical assistance with protein analysis.

\section{LITERATURE CITED}

Kusuda R, Kawai K (1998) Bacterial diseases of cultured marine fish in Japan. Fish Pathol 33:221-227

Mammur Rashid M, Nakai T, Muroga K, Miyazaki T (1997) Pathogenesis of experimental edwardsiellosis in Japanese flounder Paralichthys olivaceus. Fish Sci 63:384-387

Miyazaki T, Kaige N (1985) Comparative histopathology of edwardsiellosis in fishes. Fish Pathol 20:219-227

Nakatsugawa T (1983) Edwardsiella tarda isolated from cultured young flounder. Fish Pathol 18:99-101 (in Japanese with English abstract)

Schneider WC (1957) Determination of nucleic acids in tissues by pentose analysis. In: Colowick SP, Kaplan NO (eds) Methods in enzymology, Vol III. Academic Press, New York, p 680-684

Submitted: March 24, 2000; Accepted: August 8, 2000 Proofs received from author(s): September 18, 2000 